DOI 10.18551/rjoas.2021-09.21

\title{
THE ANALYSIS OF DEVELOPMENT DISTRIBUTION OF CLAUSE SEED AT PT TRI BERKAT AGRO
}

\author{
Simbolon Desi Kristiani* \\ Sekolah Bisnis, Institut Pertanian Bogor, Indonesia \\ Yuliati Lilik Noor \\ Departemen IImu Keluarga and Konsumen, Fakultas Ekologi Manusia, \\ Institut Pertanian Bogor, Indonesia \\ Kirbrandoko \\ Sekolah Bisnis, Institut Pertanian Bogor, Indonesia \\ *E-mail: kristiani.desi@gmail.com
}

\begin{abstract}
Agriculture is one aspect that is very important to be developed in every country. From 1984 to 2014, the ministry of agriculture launched 2,221 horticultural seed varieties to the market, where most of the 1,985 varieties were fruit and vegetable crops. There are several seed companies in Indonesia PT Clause Indonesia as one of a seed producer does not market its products directly but appoints PT Tri Berkat Agro to market Clause seeds in Indonesia. As the only company that markets seeds in all areas, the company has several things that want to be maximized, including how the performance of Clause seed distribution, explaining what indicators are the success distribution and how to develop an effective and efficient Clause seed distribution strategy. The analysis begins by conducting a portfolio in each region using several indicators such as the number of seeds, the number of shop partners, the number of field officers, and the sales value achieved. After the regional portfolio is determined, an analysis of internal and external factors will be carried out to decide which distribution development strategy will be determined for the company. In addition, management also conducts a SWOT analysis to determine the best strategy from the previous regional portfolio analysis data. The results of the distribution development obtained are that the company needs to pay attention to several aspects such as increasing the number of seed varieties, increasing the number of shops and providing promos both to shops and farmers as well as developing human resources where field officers who have knowledge of agriculture and build good communication with shops in their respective regions.
\end{abstract}

\section{KEY WORDS}

Distribution, field representative, seed, strategy, SWOT analysis, varieties of seed.

The ministry of agriculture recorded (up to 2014) 62 companies listed as cultures or breeders in Indonesia (2015, horticultural institute). The variety of the commodity can be seen from the number of varieties already launched in the agricultural market. Some companies that market seeds in Indonesia include PT BISI Internasional, PT East-West Seed Indonesia, PT Tanindo Subur Prima, PT Tani Unggul PT Sang Hyang Seri, and PT Clause Indonesia. PT Clause Indonesia, citing PT Tri Berkat Agro (TBA) to market its seed in Indonesia. PT TBA has been distributing Clause seeds since 2012 in some areas that have horticultural agricultural potential. Some areas are like West Java, East Java, Central Java, West Sumatra, and North Sumatra provinces. PT Clause Indonesia had 62 varieties of seeds already listed in Indonesia. Each region of Indonesia has varying agricultural potential, so each seed marketed has varying market potential. This makes the distribution of seeds across the country different so that more efficient and effective distribution development strategies are needed. 
In addition to Indonesia's large population and growing demand for food as well as one of the factors that should be considered why this business should be maintained, some factors should also be considered by companies regarding the seed business: First, Indonesia has a long history in agriculture so that agriculture is still an important part of the economy, both in meeting domestic needs and for export commodities. Second, Indonesia has a tropical climate, with sufficient sunlight and rain. This condition creates a stable demand for hybrid seeds that not only give high results but also have the resilience of pests, diseases, and inhospitable weather. Third, the Indonesian government has a strong commitment and focus on self-sufficiency. (2017, International Annual Report PT BISI). PT TBA is one of the companies that shows the pattern of second-tier marketing channels, the pattern of second-tier marketing channels has two intermediary businesses between manufacturers and consumers. The first intermediary is usually called the main didtributor or large merchant and the second intermediary is usually the shops. ( Sumarwan 2016).

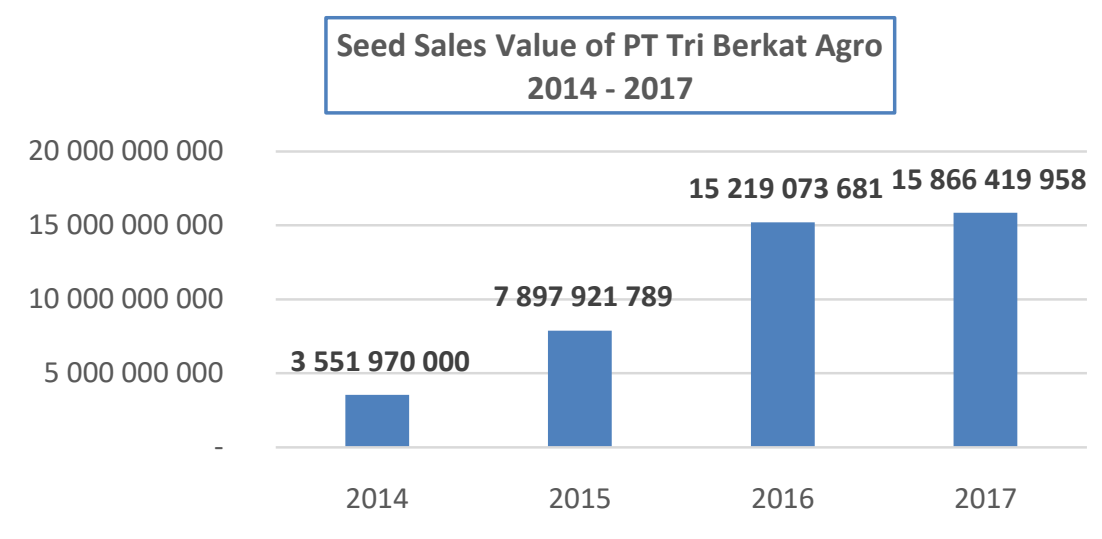

Figure 1 - Sales data at PT Tri Berkat Agro

The marketing of CLAUSE seed products grows increasingly prevalent. Sales of companies also show increased yield and increased seed production in existing areas or new ones to increase corporate revenues. PT TBA is one of the companies that shows the second level marketing channel pattern, the second level marketing channel pattern has two intermediary business actors between producers and consumers. The first intermediary actors are usually called the main didtributor or wholesaler and the second intermediary is usually the shops. (Sumarwan 2016). PT Tri Berkat Agro tried to provide the best products and services to help the company grow so that the sale of CLAUSE seed in Indonesia can achieve the corresponding sales value of the targeted value each year. Seed distribution is increasingly creative, so companies need to identify several indicators to further develop strategies in distributing seeds.

\section{METHODS OF RESEARCH}

This research is based on observations and interviews made in PT Tri Berkat Agro and PT Clause Indonesia, the method used was with special studies of identifying and connecting factors understudy to address the issues and interviews to identify indicators and planning development strategies. This research was conducted at PT Tri Berkat Agro, a company that distributes and markets horticultural seeds in Indonesia, located in Tangerang. This data collection was carried out in 6 months, namely October 2018 - March 2019. The study uses data sources primary and secondary data. Primary data is obtained through personalized. Secondary data contains sales information and expenses collected from PT Tri Berkat Agro. Here is a general description of the research process that is carried out: 


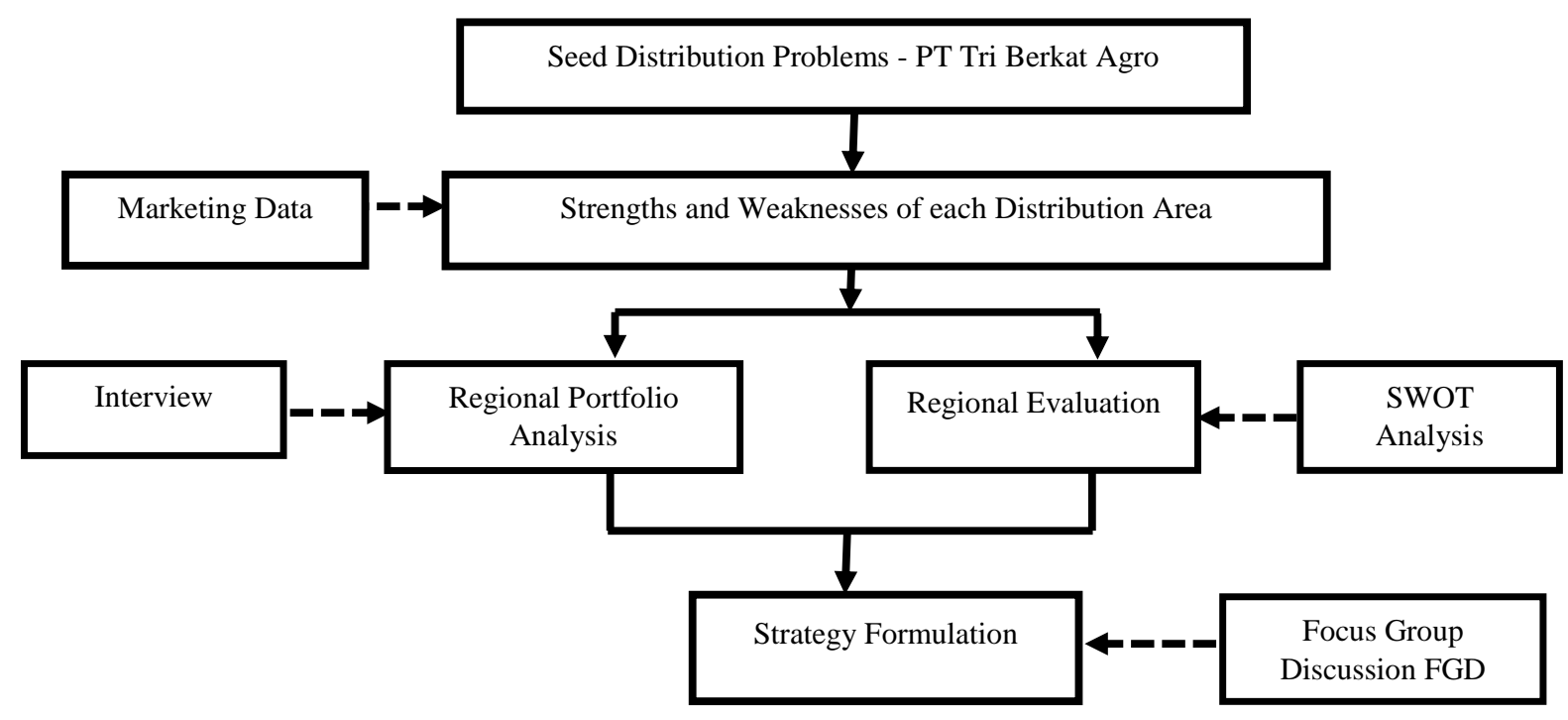

Figure 2 - Research Framework

\section{RESULTS AND DISCUSSION}

Clause was one of the seed companies that settled in France. HM Clause was a prominent seed company and distributed its seed in territories of Europe and the United States. Initially, PT Clause Indonesia distributed its seeds directly to several stores in Indonesia, especially in Java. This distribution lasted for several years until finally, the company appointed PT Tri Berkat Agro to be the only company that marketed Clause seeds throughout Indonesia. PT Tri Berkat Agro was established in Jakarta in 2013 and started marketing Clause seeds at the end of 2013. Clause seeds are one of the seeds that produce a lot of horticultural seeds. Clause seed marketing is carried out by selling products to various stores around the agricultural area. The distributor company markets Clause seeds to several provinces in Indonesia, including West Java, Central Java, East Java, North Sumatra, and West Sumatra. In 2013 and 2014, the company only sold its seeds in three regions in Indonesia, namely West Sumatra, North Sumatra, and East Java.

Regional Distribution Performance. The company's distribution area generally covers all agricultural areas in Indonesia. These areas are West Java, Central Java, East Java, North Sumatra, and West Sumatra. These areas have their own uniqueness. It is influenced by environmental factors and characteristics of different areas. Stake distribution performance discussions will give a general picture of the distribution of seed seeds in each region. The table provides information regarding some areas that are data sources in viewing distribution performance in each region. Several aspects are the number of seeds distributed, the number of stores that are partners with distributors, the number of field officers, the sales value of seeds, and promotional costs distributed in each region. The total number of seeds is 53 varieties in 2015-2016 and 51 varieties in 2017.

The basic aspect of the performance of the distribution of seed marketing is this:

Table 1 - The data obtained to analyze the performance of the Regional Distribution

\begin{tabular}{lllllll}
\hline Aspect & Year & West Java & Central Java & East Java & West Sumatra & North Sumatra \\
\hline \multirow{2}{*}{$\begin{array}{l}\text { The number of seeds } \\
\text { received by the market }\end{array}$} & 2015 & 17 & 27 & 28 & 17 & 20 \\
& 2016 & 21 & 23 & 29 & 19 & 21 \\
& 2017 & 21 & 23 & 25 & 8 & 22 \\
\multirow{2}{*}{ Number of Shop Partners } & 2015 & 27 & 43 & 41 & 19 & 21 \\
& 2016 & 19 & 45 & 27 & 16 & 17 \\
\hline \multirow{2}{*}{ District Officer } & 2017 & 24 & 27 & 29 & 13 & 3 \\
& 2015 & 2 & 2 & 2 & 4 & 2 \\
\hline
\end{tabular}


Specifically, each region has a unique distribution performance. West Java has $32 \%$ or around 17 varieties of seeds among several varieties belonging to the cabbage, chili, broccoli, and mustard seed groups. Seed varieties widely marketed in West Java are still dominated by seeds widely marketed around Lembang and Garut. Seed distribution in West Java is scattered in several locations such as Lembang, Garut, Tasikmalaya, Cianjur, Purwakarta, and several other areas. The number of seed varieties received by partners and farmers is seventeen, which is quite a lot, considering that West Java is a new region compared to several other regions. The number of shop partners in the region, in general, suffered a reduction in 2016 and improved back in 2017 by adding to its marketing locations to the region's elections. The chart shows that the percentage of the seed's sales value increases annually. Cabbage seeds, cabbage, chili peppers, broccoli, and peppers are various seeds that contribute the largest sales value to the sale of seeds in west Java, some of which provide power for West Java. Among other things, west Java distribution power is a field representative and an area coordinator who has capable agricultural experience.

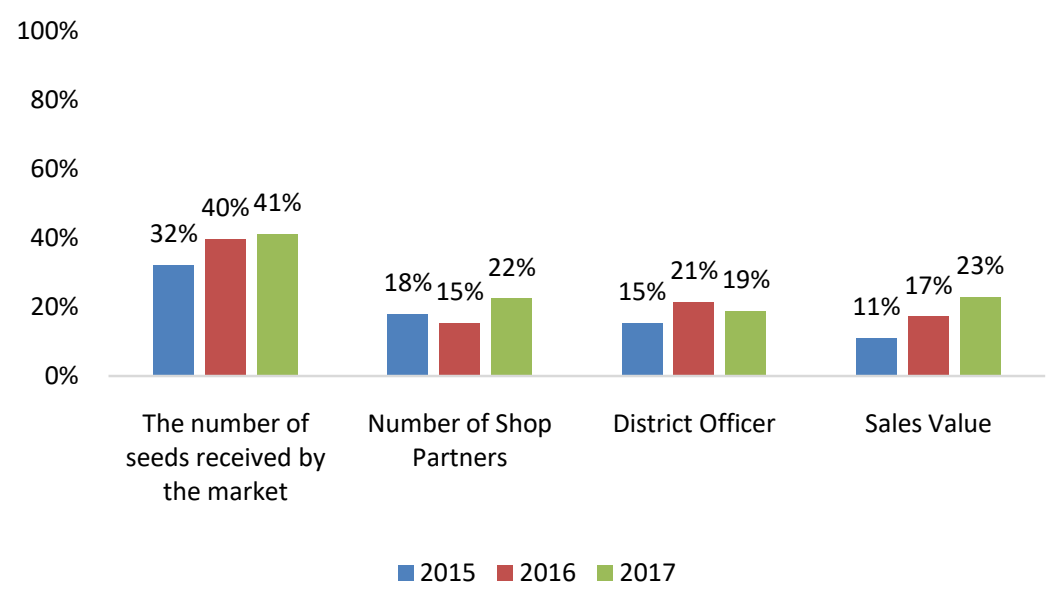

Figure 3 - Graph of Distribution Performance in West Java Region

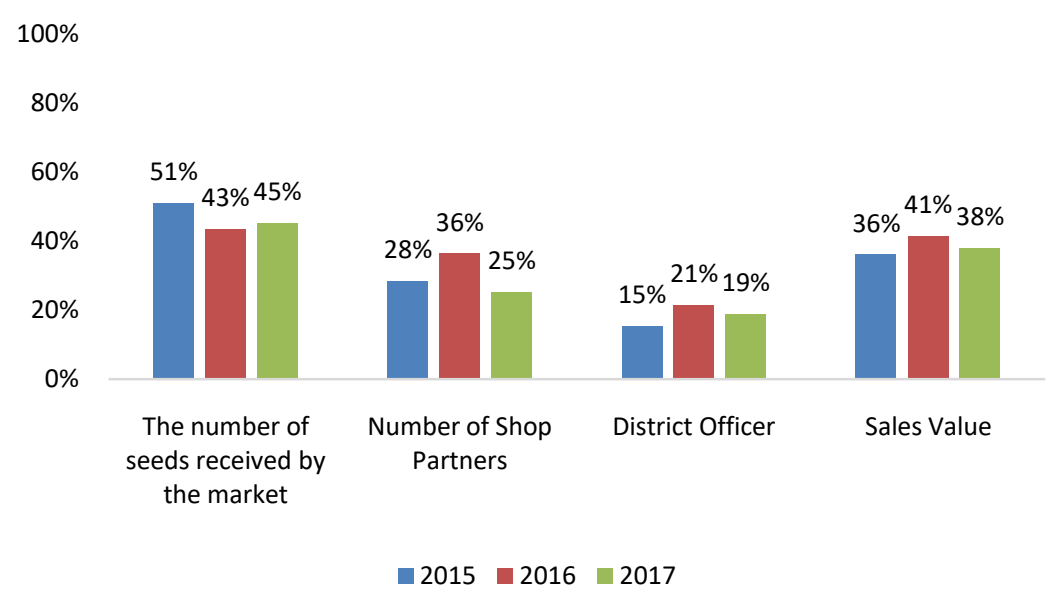

Figure 4 - Graph of Distribution Performance in Central Java Region

Central Java is one of the regions in Indonesia that has good agricultural products. In general, horticultural agricultural products in Central Java are distributed to Central Java, East Java, and parts of West Java. The following are areas where agricultural seeds are distributed in Central Java, including Wonosobo, Magelang, Banjarnegara, Boyolali, and other areas in Central Java. Some of these areas were key areas for seed distribution for three periods. The number of seeds distributed in Central Java had experienced a reduction. This reduction in the number of seeds is a decision made directly by a global company and 
not at the distributor's will. The reduction in the types of seeds marketed was due to the lack of demand for these seeds, so the company had to stop the production process. The graph shows the number of shops; the processed data provides information that the number of stores marketing Clause seeds increased in 2016, from 43 stores to 45 stores. The increase in the number of shops is because the market in Central Java is experiencing an increase in demand, so that companies add partners who work together.

The area of horticultural agriculture in East Java is centered in Malang, and so almost all horticultural seeds are supplied to the region. Figure 4 shows that the percentage of the number of seeds distributed has increased in 2016 and decreased in 2017. The increased number of seeds in 2016 is due to distributors trying to open markets to several new areas that plant fruit seeds such as watermelon and melons.

The reduction in the number of seeds in 2017 was influenced by several products that were no longer reproduced by PT Clause Indonesia due to lack of interest in the market, so seed production had to be stopped. The percentage of the number of stores has decreased in 2016 and has increased in 2017. The reduction in the number of stores in 2016 is one of the company's steps to select stores committed to working well together. The increase in the number of stores in 2017 was due to the improved relationship between partners and distributors.

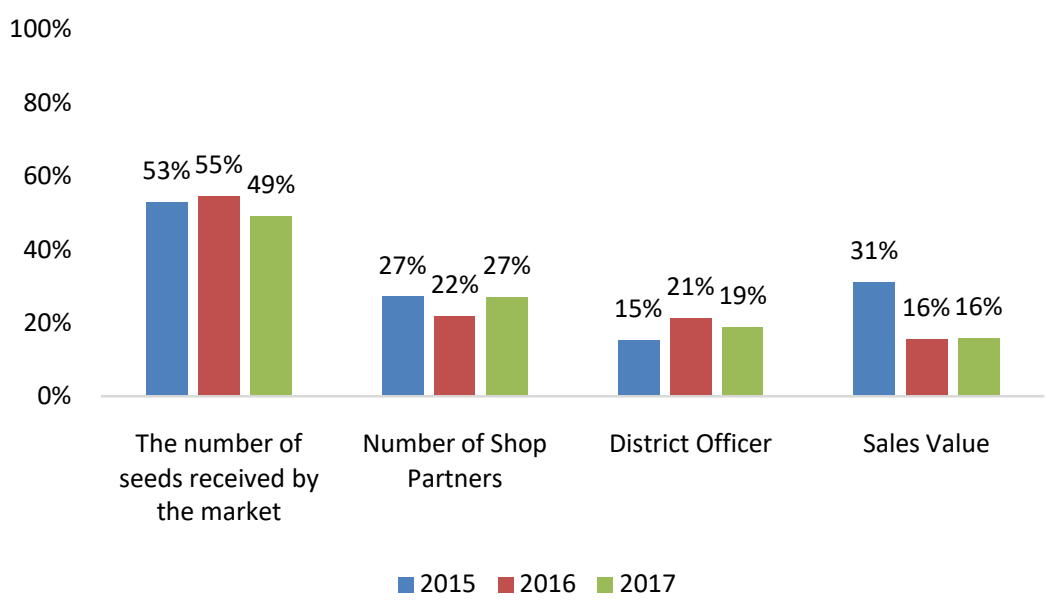

Figure 5 - Graph of Distribution Performance in East Java Region

West Sumatra is one of the areas with highlands, which are generally used for horticultural agricultural cultivation. Agricultural cultivation areas in West Sumatra include Solok, Payakumbuh, and Kayu Aro districts. The graph of the number of seeds distributed in West Sumatra in 2016 has increased. However, in 2017 the number of seeds marketed has decreased because West Sumatra has a very special market, and competitors have already mastered it. The percentage of shops in West Sumatra is classified as stagnant or has not experienced a drastic change. It is because the number of agricultural lands and the number of agricultural shops in the area is very limited. Also, the usually used locations for agricultural cultivation are quite far from one region to another. The information on the percentage of shops in West Sumatra is classified as stagnant or has not changed the number of field officers in the West Sumatra in 20154 people, in 2016 the company tried to reduce field officers because of making officers efficient at locations. This is deemed inappropriate because it has an impact on the decline in sales value. In 2017 the company added field officers so that all areas of West Sumatra could be well monitored, but this also did not significantly affect sales value. The sales value in West Sumatra continues to decline in several aspects, including the decrease in field officers, and in 2017 some seeds were seeded for distribution but were not available. 


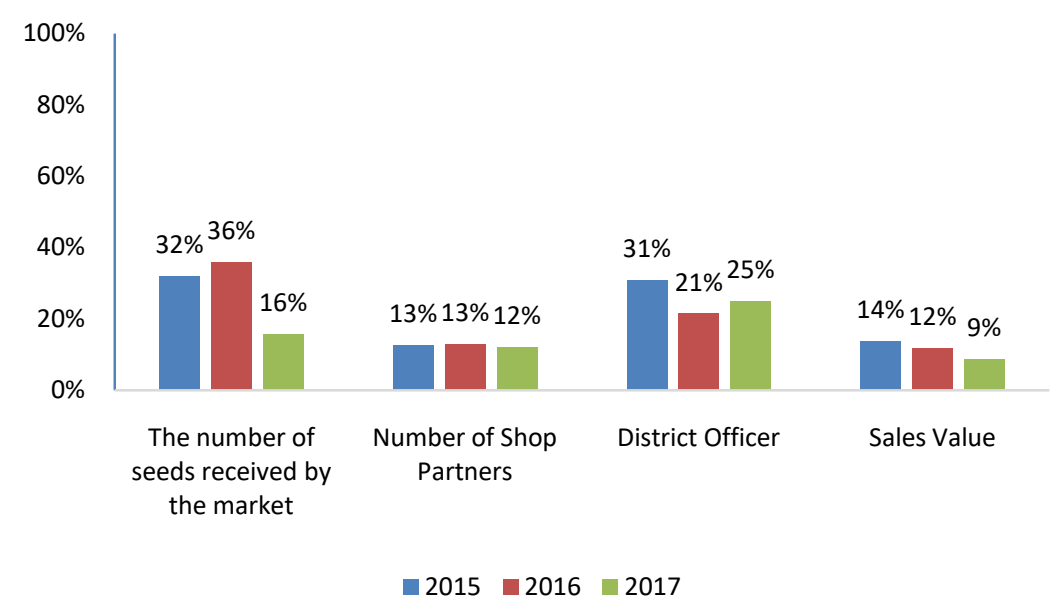

Figure 6 - Graph of Distribution Performance in West Sumatera Region

North Sumatra has highlands, which are generally used to cultivate horticultural crops, several locations for vegetable planting centers, including Siborong-Borong, Sidikalang, and Berastagi. In the graph of the regional distribution performance, it can be seen that the percentage of the number of seed varieties distributed each year. The number of seed varieties distributed increases by one each year. The graph also shows the number of stores in North Sumatra that have experienced a reduction due to less committed stores. This is because the number of shops in North Sumatra was initially not too many, and the shops selected as partners were already quite large stores. Something unique to the distribution of seeds in northern regions was vegetable wholesalers, who were also agents. Distribution of seeds by giving seeds specifically to farmers so that this also reduces the number of shops in North Sumatra. The graph showing information on field officers in the North Sumatra experienced a reduction in the number of field officers in 2016 and re-recruiting field officers for 2017. The increase in the number of officers in 2017 in North Sumatra affected the value of sales in this region.

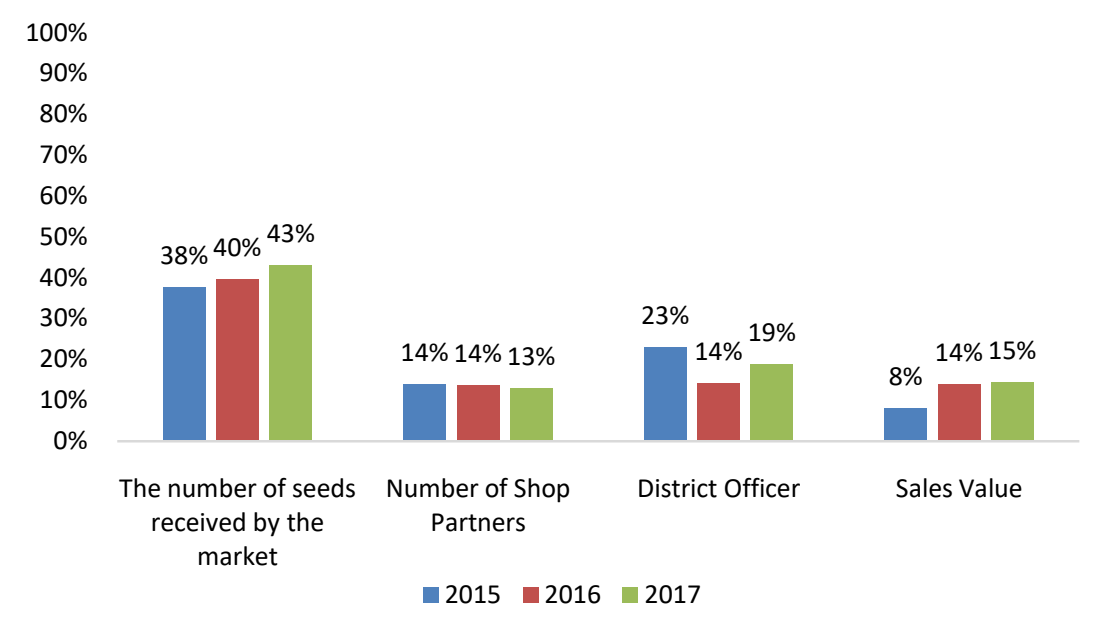

Figure 7 - Graph of Distribution Performance in North Sumatera Region

North Sumatra has highlands, which are generally used as the location for horticultural cultivation, several locations including Siborong-borong, Sidikalang, and Berastagi. The Figure 7 shows that the percentage of the number of seed varieties distributed each year has increased, although not significantly. In the three years, the performance period in the North Sumatra region showed an increase. The graph showing the number of shops in North Sumatra shows the number of shops that are fixed. This is because the number of shops in the North Sumatra Region is not too many, and the stores chosen to partner are already 
quite large. The graph that shows the number of field officers in the North Sumatra region experienced a reduction in the number of field officers in 2016, and re-recruited field officers for 2017. The increase in the number of officers in 2017 in the North Sumatra region affected sales in this region.

Regional Portfolio Analysis. Regional Portfolio analysis is one of the methods used to summarize and function to determine the quality of each region compare to other regions in several aspects:

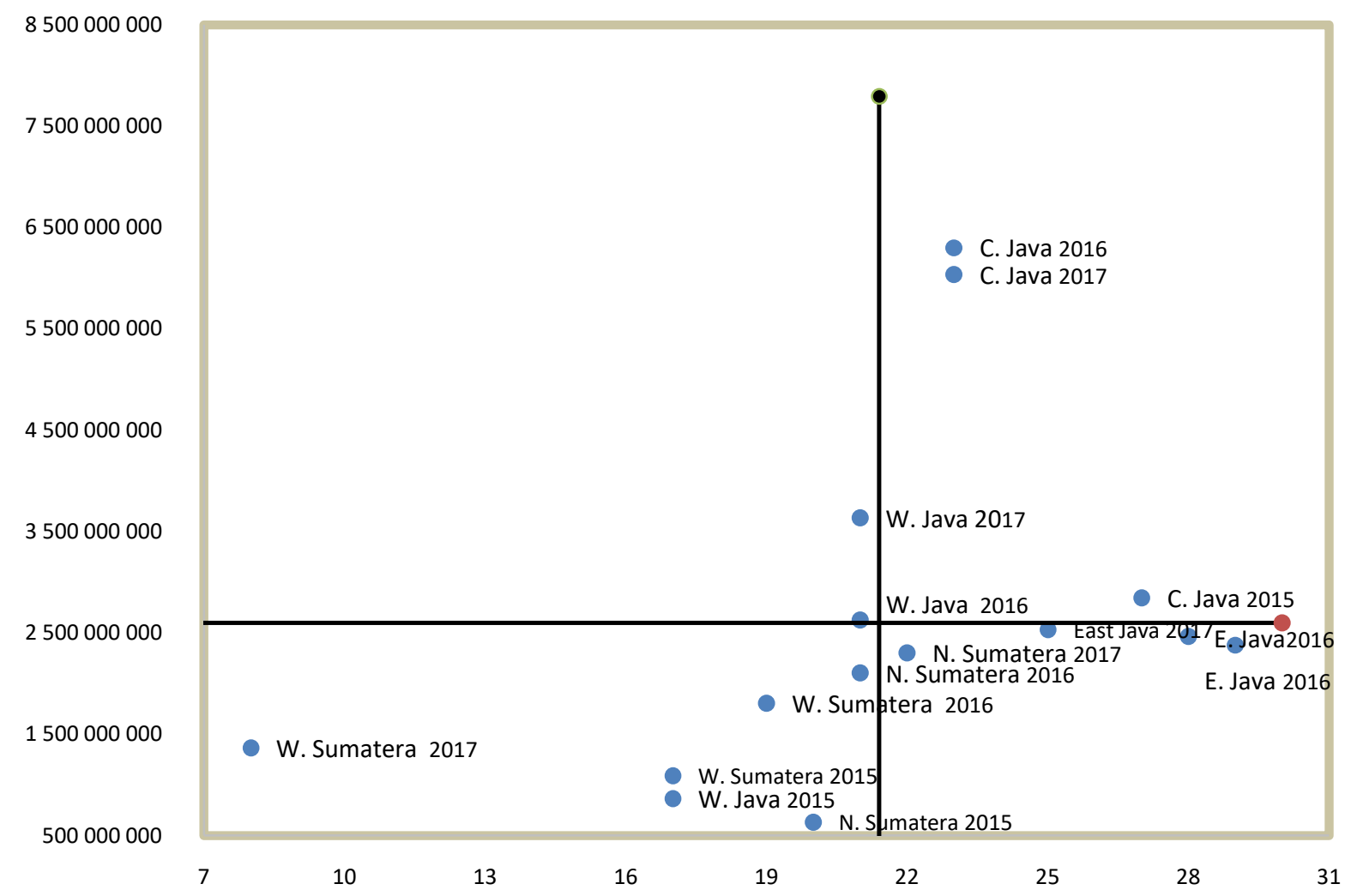

Figure 8 - Portfolio Number of Seed Varieties with Sales Value Note: X: Number of Stores; Y: Income Value

The portfolio of the number of seed varieties marketed generally gives an undirectional impact where most parts of the region that market many seed varieties also get high sales value. A different thing is shown in the west java region, which has several seed varieties less than other regions but has a high selling value. Determining the type of seed that is in accordance with the farmer's request is an important aspect. The Figure 8 provides information that Central Java is one of the regions with a straight comparison of the number of seed varieties with sales value. The Region of East Jawa is one of the Companies concern because the number of seed varieties being marketed is large but does not show an appropriate sales value.

Portfolio of the number of stores with sales value, It is found that the number of shops affects the sales value in the region too much, as shown by the sales value of east Java, which does not show the same value as the increasing number of partners who work together.

In the portfolio of the number of stores with sales value, it is found that the number of stores in a region does not affect the sales value. The Central Java and East Java regions have more stores than other regions. However, the results obtained by comparing with the sales value show that the Central Java region shows a value in the direction of the increase in the number of shops, but the number of stores in East Java does not show the same value. 


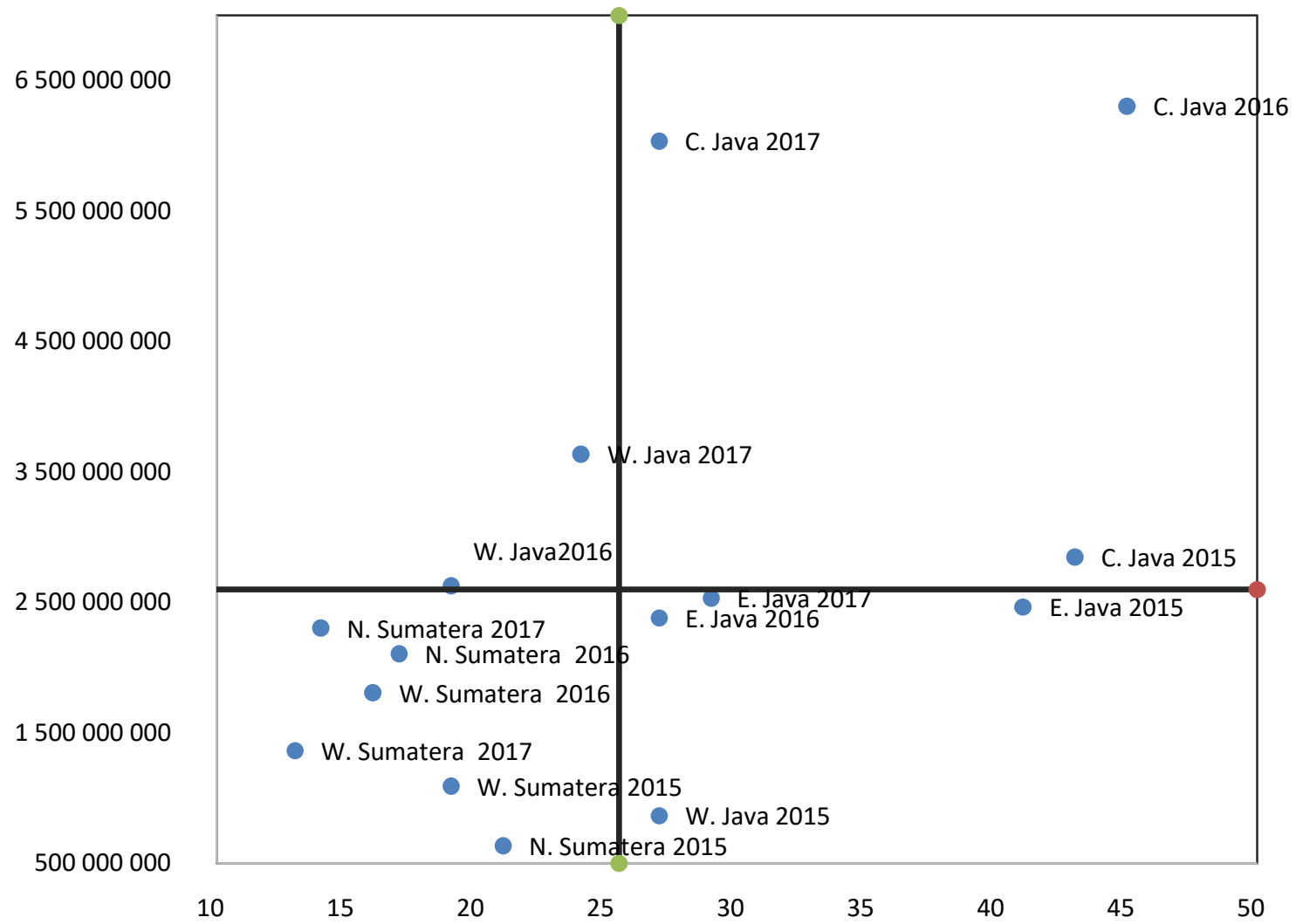

Figure 9 - Portfolio Number of Stores Varieties with Sales Value Note: X: Number of Stores ; Y: Income Value

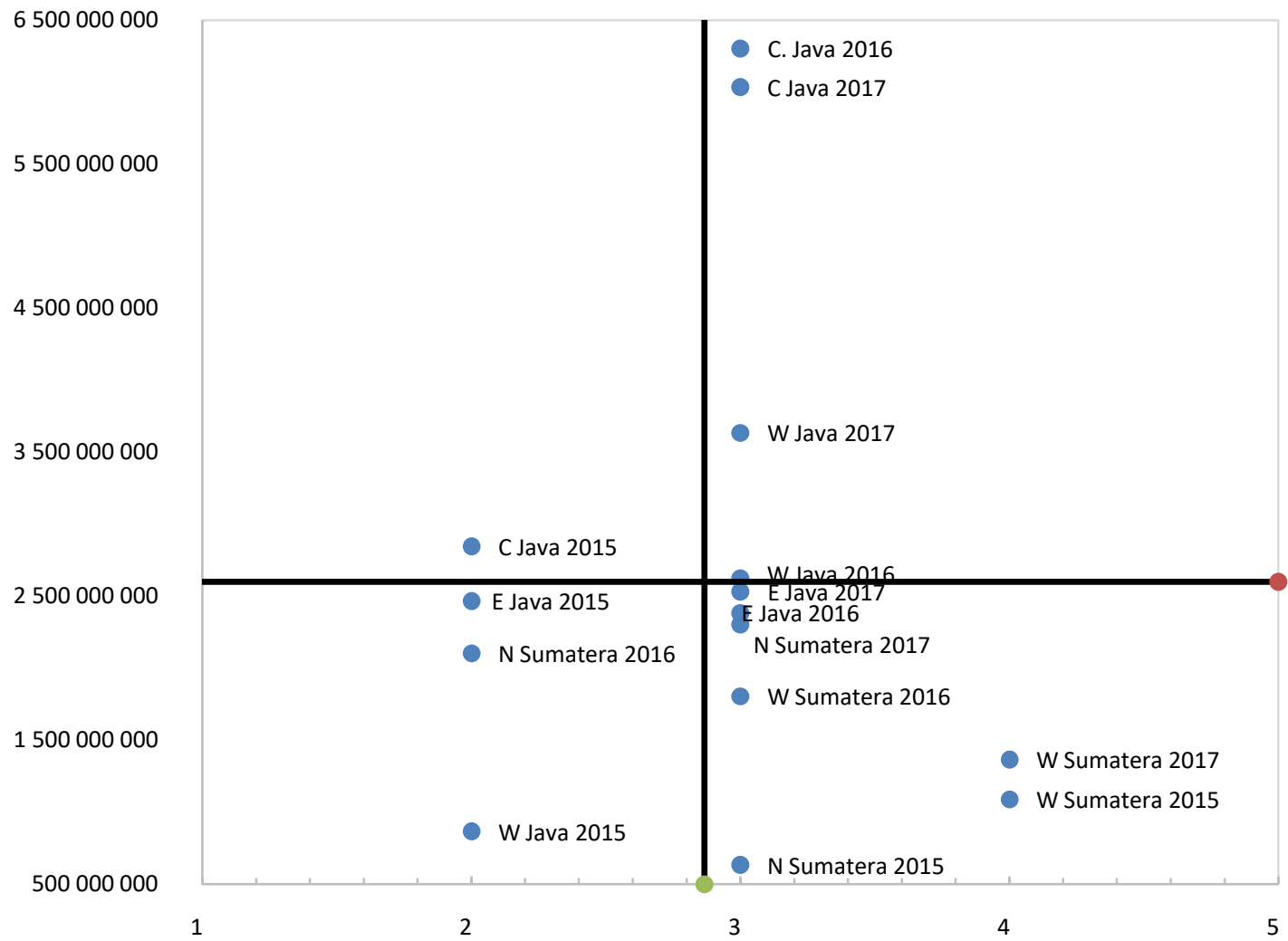

Figure 10 - Graph of Number of Officers and Sales Value from 2015 to 2017 Note: X: Number of Stores ; Y: Income Value 
The field officers or Human Resources (HR) portfolio shows more field officers in the Central Java region and produces the highest sales value. In general, field officers in charge of each area have carried out their responsibility to properly distribute Clause seeds. Through several telephone interviews, the obstacles in maximizing the responsibility of field officers were the lack of confidence in explaining Clause products, in addition to the lack of activities or meetings between officers and farmers who planted or did not plant Clause seeds.

Internal Factor Evaluation Results. Evaluation of internal factors is one of the things that is determined before determining future strategy. Internal factors that have been discussed and determined include the strengths and weaknesses factors in general related to the distribution of the company so that the following points are obtained;

Strength Factor:

- Clause seeds that are marketed have good quality, as evidenced by the yield of seed growth (germination), which has a percentage of more than $70 \%$ in each package sold;

- Friendly field staff and good relationship with shop partners;

- The price of Clause seeds that are marketed in stores is relatively competitive so that the shop partners can take sufficient profit for each product;

- Adequate accommodation for officers.

Weakness Factor:

- The number of seed varieties is still less varied, so they still rely on some superior seeds;

- Provide promotions for stores so that the distribution of seeds is better done and maximized;

- Field officers who are not very proficient in agriculture;

- Limited shop partners.

Results of External Factors Evaluation.Evaluation of external factors is one of the things that is determined before determining future strategy. External factors that have been discussed and determined include opportunities and threats in general related to the distribution of the company so that the following points are obtained;

Opportunity Factor:

- Variety of seeds ranging from vegetable seeds, flower seeds, and other ornamental plant seeds;

- Take advantage of the moment of "healthy living" in the community to create a desire to plant in the community;

- Government regulations related to limiting the distribution period of imported seeds in Indonesia;

- There is a nursery available for production.

Threat Factors:

- Local seed companies that do not have a license but market their products illegally without getting official recognition from the government regarding seed quality;

- Competitors with more advanced field staff;

- Unique seeds;

- Climate change and natural environment that does not match predictions.

All factor indicators that have been determined are written in the table so that several alternative strategies are found as follows in Table 2.

Company strategy in general determines the orientation of the company towards growth and the industry or market it will enter. (Hunger David, Wheelen Thomas. 2003), there are some of company strategy:

Strength - Opportunities (S-O) Strategy:

1. Creating new seed varieties. New seed varieties should be created with good quality like other seeds. So that farmers' confidence in Clause seeds does not decrease. The seed varieties will increase each time, so the company will always innovate to provide the latest and quality products. 
2. Campaign to grow vegetables at home. A healthy lifestyle is one of the things that is happening recently, so the company is trying to make good use of this moment so that more people, both farmers and hobbyists, are planting so that the distribution of seeds can also reach their homes.

3. Use accommodations to find new territories. The accommodation provided is intended so that field officers can more freely carry out activities and activities to support seed distribution. Besides, it is also hoped that field officers can find new areas to develop into areas that have the potential to develop seed distribution.

Table 2 - Internal and External Factors

\begin{tabular}{|c|c|c|}
\hline \multirow[b]{2}{*}{ Factors } & Strengths & Weaknesses \\
\hline & $\begin{array}{l}\text { 1. Good quality seeds that have been } \\
\text { recognized by farmers } \\
\text { 2. Friendly field staff } \\
\text { 3. Relatively competitive price of Clause seeds } \\
\text { 4. Adequate accommodation for officers } \\
\text { 5. Good Brand Awareness at Global Level }\end{array}$ & $\begin{array}{l}\text { 1. Fewer seed varieties and slow } \\
\text { launch } \\
\text { 2. Lacking promotion for stores } \\
\text { 3. Field Officer } \\
\text { 4. Limited store partners }\end{array}$ \\
\hline Opportunities & \multirow[b]{2}{*}{$\begin{array}{l}\text { 1. Creating new varieties with good quality } \\
\text { seeds } \\
\text { 2. Campaign to grow one's own vegetables at } \\
\text { home } \\
\text { 3. Accommodation is used to find new areas }\end{array}$} & \multirow[b]{2}{*}{$\begin{array}{l}\text { 1. Cooperate with leading } \\
\text { research institutes } \\
\text { 2. Give promos to stores for } \\
\text { special seeds } \\
\text { 3. Human resource development }\end{array}$} \\
\hline $\begin{array}{l}\text { 1. Special seed varieties } \\
\text { 2. Take advantage of the moments of } \\
\text { Healthy Living } \\
\text { 3. Government regulations } \\
\text { 4. Available nursery area }\end{array}$ & & \\
\hline Threats & \multirow{2}{*}{$\begin{array}{l}\text { 1. Provide education to farmers } \\
\text { 2. Maintain product quality } \\
\text { 3. Sustainable production } \\
\text { 4. Human resource development }\end{array}$} & \multirow{2}{*}{$\begin{array}{l}\text { 1. Maintain product quality } \\
\text { 2. Addition of experts }\end{array}$} \\
\hline $\begin{array}{l}\text { 1. Local seed companies } \\
\text { 2. Officers from Competitors } \\
\text { 3. Unique vegetable seeds } \\
\text { 4. Climate Change }\end{array}$ & & \\
\hline
\end{tabular}

Weakness - Opportunities (W-O) Strategy:

1. Cooperate with leading research institutes. This collaboration is carried out so that more seed varieties can be distributed to expand new distribution channels for new areas or develop existing ones.

2. Provide promotional activities at the store. Promotional activities carried out in stores can be created so that the Clause brand is increasingly recognized by farmers or shops and, at the same time, help the store to ease distribution and promotion activities related to Clause seeds. This form of promotion is a new way of attracting new or never-beforedistributed Clause seeds.

3. Human Resources Development (HR). Development of Human Resources (HR) currently exists to compete with other officers to describe or represent the seeds of Clause well. Hold training related to agriculture and discussions related to current agricultural issues to add insight for field officers.

Strength - Threats (S-T) Strategy:

1. Provide education to farmers. Provide education or information to farmers regarding official and unofficial seeds. Registration of seeds at the Ministry of Agriculture is an important matter related to the sustainability of these seeds in Indonesia. So we have to provide knowledge to shops and farmers so that they do not get trapped with unregistered or unofficial seeds.

2. Maintaining the quality of seed products. The success of Clause seeds in maintaining good seed quality is well known to farmers and shops. So that companies and research teams must adhere to the vision to always provide the best quality seeds.

3. Sustainable production. Sustainable production is one of the important strategies; in this case, the company must try to see and predict the availability of seeds at certain times so that the seeds are not empty.

Weakness - Threat $(W-T)$ Strategy:

1. Maintaining product quality. The success of Clause seeds in maintaining good seed quality is well known to farmers and shops. So that companies and research teams must adhere to the vision to always provide the best quality seeds to farmers.

2. Addition of Experts. Farmers' confidence will increase in the marketed products when they can discuss with an expert in agriculture so that this trust can also increase the 
expansion of the distribution of seeds to be marketed. Experts are needed in every industry to provide education or views based on their expertise.

Managerial Implications. The analysis results in several Clause seed distribution areas showed that the currently available seed varieties were still very limited and still superior in certain areas. Most of the seed products marketed are highly superior in the medium to highland areas, so distributors must work with seed producers to create new and unique seed products of good quality for the medium to lowlands. The addition of varieties may also be created by collaborating with existing research institutions.

Promotion is a good form to do in developing and expanding product distribution. Promotions given to partners or shops, even farmers, can be more and more attractive, affecting seed distribution expansion. Increasing the number of shops can also be a matter that should be considered so that more shops or partners sell Clause seeds and the easier it is for farmers to get.

Human resources are one of the most important assets in a company, so that regular human resource development is needed so that officers can develop and develop their respective areas with the team. Also, experts can provide input or suggestions for companies in the agricultural sector in a more specific manner to resolve all technical matters properly.

\section{CONCLUSION AND SUGGESTIONS}

This research attempts to answer the problems being faced by the company to maximize the distribution of seeds marketed to increase the value of seed sales. Indicators in determining distribution performance include the number of seed varieties marketed, the number of shops that are partners with the company, and field officers responsible for each region. In general, the distribution performance carried out in each region has been good, but not all regions have shown maximum results. Several alternative strategies are determined by collaborating with research institutions to create new and good quality varieties, creating attractive promos for both shops and farmers, providing education to farmers, and developing human resources.

Suggestions:

1. Adding other distribution performance indicators so that the more indicators on which the assessment is based, the better performance reports are produced;

2. This research can be further examined by comparing with the competitor company's distributor strategy to make it better.

\section{REFERENCES}

1. BISI International. 2015. International Annual Report PT BISI (ID). Bisi International.

2. Direktorat Jenderal Hortikultura. 2015. Katalog Pengawasan Peredaran Benih Hortikultura. Jakarta (ID): Direktorat Jenderal Hortikultura.

3. Hunger David, wheelen Thomas. 2003. Manajemen strategis. Agung Julianto Penerjemah; Agung julianto, editor. Yogyakarta (ID). Andi.

4. Joseph Gultinan. 1990. Strategi and Program Manajemen Pemasaran Ed ke 2. Jakarta.

5. Kotler P, Keller KL. 2012. Marekting Management. Ed ke 14. US: Prentice Hall.

6. Rangkuti. 1998. Analisa SWOT: Teknik Membedah Kasus Bisnis. Gramedia Pustaka Sinar Utama. Jakarta.

7. Sumarwan U, Djunaidi A, Aviliani, Singgih HCR, Sayono JA, Budidarno RR Rambe S. 2009. Pemasaran Strategik: Strategi untuk Pertumbuhan Perusahaan dalam Penciptaan Nilai bagi Pemegang Saham. Ed ke -1. Jakarta (ID): Inti Prima Promosindo.

8. Sumarwan,U. 2016 Pemasaran Strategik: Perspektif Perilaku Konsumen and Marketing Plan.Sumarwan U, editor. Bogor (ID): IPB Pr.

9. Iskandar H. 2016. Strategi Pemasaran PT Pola Lubindo. Journal of Business and Managemnt. 52 (11): 68-80.

10. Rendel H. et al, 2018. Marketing Analysis of Local Chicken Egg (Galus Domestic) in Pematang Siantar, North Sumatera: Indonesian Journal of Agr.I Research 1(2): 112-122. 